\section{Irrigation Water Acidification to Neutralize Alkalinity for Nursery Crop Production: Substrate pH, Electrical Conductivity, Nutrient Concentrations, and Plant Nutrition and Growth}

\author{
Joseph P. Albano ${ }^{1}$ \\ U.S. Horticultural Research Laboratory, USDA-ARS, Fort Pierce, FL 34945
}

James Altland

Application Technology Research Unit, USDA-ARS, Wooster, OH 44691

Donald J. Merhaut

University of California-Riverside, Riverside, CA 92521

Sandra B. Wilson and P. Chris Wilson

Institute of Food and Agricultural Science, University of Florida, Gainesville, FL 32611

Additional index words. carbonate, bicarbonate, controlled-release fertilizer (CRF), runoff, water quality, thryallis, Galphimia glauca, Galphimia gracilis

Abstract. Liming agents (LAs) in irrigation water, typically associated with carbonates and bicarbonates of calcium (Ca) and magnesium (Mg), contribute to water alkalinity. Repeated application of LA to container crops can cause media-solution pH to rise overtime, that uncorrected, can lead to a nutrient availability imbalance that may be suboptimal for plant-growth due to nutrient disorder(s). To correct high levels of LA in irrigation water, growers can inject acid into their irrigation system to neutralize alkalinity. Therefore, a 52-week study was conducted using irrigation water, substrate, and plants from a commercial nursery in Florida that has a history of poor water quality and plant production problems related to high alkalinity irrigation water. The objectives of the study were to assess substrate $\mathrm{pH}$, electrical conductivity (EC), and nutrients, and plant nutrition and growth for thyrallis (Galphimia gracilis Bartl.) to irrigation water acidification. Treatments consisted of irrigation water acidified with sulfuric acid $\left(\mathrm{H}_{2} \mathrm{SO}_{4}\right)$ to neutralize $0 \%$ (control), $40 \%$, or $80 \%$ of calcium carbonates $\left(\mathrm{CaCO}_{3}\right)$ yielding $\mathrm{a} \mathrm{CaCO}_{3}\left(\mathrm{meq} \cdot \mathrm{L}^{-1}\right) / \mathrm{pH}$ levels of 5 [High Alkalinity (H-A)]/7.37, 3 [Medium Alkalinity (M-A)]//6.37, and 1 [Low Alkalinity (L-A)]//4.79, respectively. Substrate analysis by the 1:2 dilution method at the end of the study was significant $(P<0.05)$ for $\mathrm{pH} 6.2,5.2$, and 4.7 for the H-A, M-A, and L-A treatments, respectively, and for nutrients Ca, Mn, and Zn. Foliar nutrient levels were statistically significant $(P<0.05)$ for alkalinity treatment for $\mathrm{Fe}, \mathrm{K}, \mathrm{Mn}, \mathrm{P}$, and $\mathrm{Zn}$. Alkalinity treatment was significant $(P<0.05)$ for growth, leaf greenness (by SPAD), and quality (by survey) with the M-A treatment producing more biomass, having greener leaves, and the highest aesthetic quality value than the $\mathrm{H}-\mathrm{A}$ or $\mathrm{L}-\mathrm{A}$ treatments. A qualitative survey of root systems at harvest showed that the M-A and L-A treatment root systems were greater than the $\mathrm{H}-\mathrm{A}$ treatment based on visual side-wall root development. These data demonstrate that irrigation water acidification does alter substrate $\mathrm{pH}$ and nutrients and plant tissue nutrient levels and growth over a long-term production cycle typical for nursery crops.

Dissolved carbonates and bicarbonates are major contributors to irrigation water alkalinity. Irrigation water alkalinity (i.e., buffering capacity), not $\mathrm{pH}$, has the major influence on substrate (the term "substrate" is interchangeable with "media" for purposes of this article) solution chemistry (Ruter, 2013). Groundwater sources in Florida are typically characterized with a $\mathrm{pH}>7.0$ and high levels of carbonates $\left(\mathrm{CO}_{3}{ }^{2-}\right)$ and bicarbonates $\left(\mathrm{HCO}_{3}{ }^{-}\right)$of calcium $(\mathrm{Ca})$, magnesium $(\mathrm{Mg})$, and possibly other cations like potassium $(\mathrm{K})$ and sodium $(\mathrm{Na})$. Such water is typically derived from a surficial $[\approx 9.14$

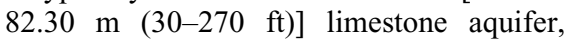
especially as you move south through the state (Fish and Stewart, 1991; Li and Zhang, 2002; Reese and Cunningham, 2000). Repeated application of high alkalinity water may cause substrate solution $\mathrm{pH}$ to rise overtime, subsequently altering substrate nutrient availability/balance to an extent that nutrient disorders develop, especially for micronutrients, and a reduction in plant growth (Bell et al., 1993; Coulombre et al., 1984; De la Guardia and Alcántar, 2002;
Kuehny and Morales, 1998; Li and Zhang, 2002; Roosta, 2011; Valdez-Aguilar and Reed, 2007). Current recommendations for correcting high alkalinity irrigation water are to either neutralize to an end-point alkalinity ( $80 \%$ neutralization of bases is recommended), or to an end-point $\mathrm{pH}$ ( $\mathrm{pH} 5.8$ is recommended) by acidification with sulfuric, nitric, or phosphoric acid (Baily, 1996; Kidder and Hanlon Jr., 1997). Surprisingly, little information outside of technical bulletins is available for assessing the long-term effects of irrigation water acidification on nursery crops.

A commercial nursery located in Fort Pierce, FL $\left(27.4467^{\circ} \mathrm{N}, 80.3256^{\circ} \mathrm{W}\right)$, that identified production problems related to high alkalinity was selected to be the source for plants, substrate, and water for the study. Affected plants at this nursery developed a general pattern of interveinal chlorosis on leaves of plants in 11.4-L containers after several months in production (Fig. 1). Corrective measures included supplemental fertilizer applications [fertilizer products varied (personal communication with grower)]. Preliminary analysis of affected plants revealed a foliar micronutrient imbalance and a $\mathrm{pH}$ greater than 6.0 for substrate extracts (data not shown). The irrigation water source for this nursery also contained a high level of carbonates and bicarbonates $[>200 \mathrm{ppm}$ $\left(\mathrm{mg} \cdot \mathrm{L}^{-1}\right)$ as $\left.\mathrm{CaCO}_{3}\right]$. To investigate this problem, we conducted a long-term (52-week) study to assess irrigation water chemistry, the effects of alkalinity level/irrigation water acidification on substrate chemistry and on plant nutrition and growth for thyrallis

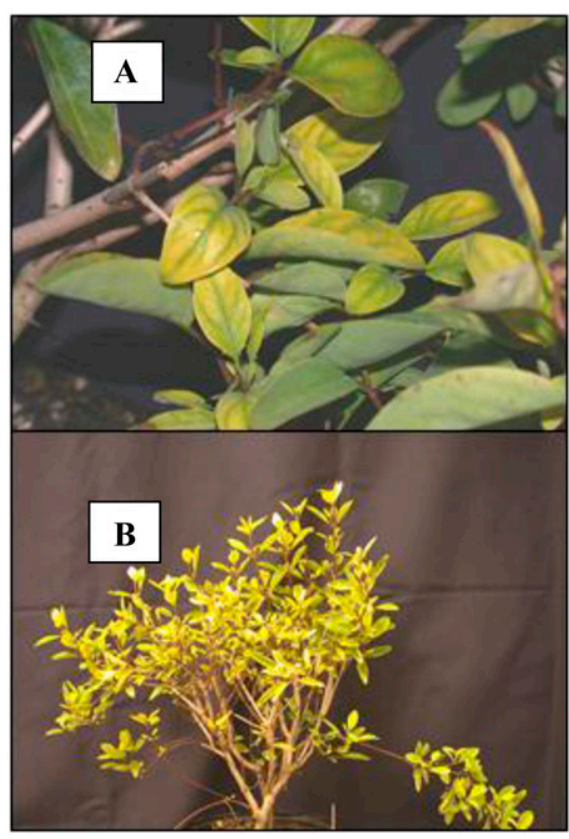

Fig. 1. Thyrallis plants collected at the same nursery that was the focus of the study. (A) Leaves showing nutrient disorder and (B) affected plant with general chlorosis and poor growth. 
grown under near-normal commercial nurserycrop production conditions.

\section{Materials and Methods}

Plant, substrate, and irrigation water source. Thyrallis plants, substrate, and irrigation water were acquired from a commercial nursery in Fort Pierce, FL, reporting production problems because of high alkalinity irrigation water. Plants were received in 11.36-L pots and had been in this size pot and substrate for $\approx 4$ months. Plants were $\approx 1$-year-old from cuttings having been stepped up from $10.16 \mathrm{~cm}$ to 3.79 -L containers before transplant into $11.36-\mathrm{L}$ containers. Substrate was composed of Florida peat, aged pine bark, sand, and other amendments as described in Table 1. Water used for irrigation (i.e., treatments) was collected from an $18.29-\mathrm{m}$ well on the same nursery. There is some debate on the correct species for thyrallis with some sources referring to it as Galphimia glauca Cav., commonly called "Rain-of-Gold" (Gilman, 1999); and some referring to it as Galphima gracilis Bartl., commonly called "Slender Goldshower" (USDA, NRCS, 2016). The latter, Galphima gracilis, is becoming generally accepted, but, however, "thyrallis" is used for both species.

Growing conditions. Plants were grown for 52 weeks in a greenhouse maintained at venting/heating temperatures of $29.4 / 23.3{ }^{\circ} \mathrm{C}$. Because controlled-release fertilizers (CRF) longevity is often based on temperature, a detailed record of environmental conditions during the course of the 52-week study is presented in Fig. 2. Plants were arranged on a greenhouse bench spaced $45.7 \mathrm{~cm}$ on the center. For more consistent growth measurements over the 52-week study, the north side of pots were marked, and plants maintained the same directional orientation on the bench throughout the study (Fig. 3A). Osmocote 196-12 (N-P-K) (Scotts-Sierra Horticultural Products Co., Marysville, $\mathrm{OH}$ ) was applied to the substrate surface at the rate of $13 \mathrm{~g} /$ pot on day 58 of the study.

Preparation of irrigation water treatments. Alkalinity level was determined directly (direct method) by titration to a $\mathrm{pH}$ end-point of 4.0

Received for publication 4 Nov. 2016. Accepted for publication 30 Mar. 2017.

We thank Chris Lasser and Loretta Myers; Biological Science Technicians, USDA-ARS-U.S. Horticultural Research Laboratory (USHRL) for technical assistance; and Nancy Burrell and Elizabeth Baldwin, USHRL, for critical review of the article. This research is in support of the USDA-ARS project "Integrated Strategies for Managing Pests and Nutrients in Vegetable and Ornamental Production Systems," project number 6034-22000-042-00D. This material is based on work that is supported in part by the National Institute of Food and Agriculture, U.S. Department of Agriculture, under award number 2014-51181-22372, USDA-ARS-Floral and Nursery Research Initiative (FNRI), and Horticultural Research Institute (HRI).

${ }^{1}$ Corresponding author. E-mail: joseph.albano@ars. usda.gov. using $0.1 \mathrm{~N}$ sulfuric acid $\left[\mathrm{H}_{2} \mathrm{SO}_{4}, 36 \mathrm{~N}\right.$ (Fisher Scientific, Pittsburgh, PA, A-304)] and the indicator bromocreosol green (Fisher Scientific, SI14-500) (Physical and Aggregate Properties, Alkalinity: Titration, 1998). For comparison, the alkalinity level was also estimated indirectly (indirect method) by calculation based on the concentration $\left[\mathrm{mg} \cdot \mathrm{L}^{-1}(\mathrm{ppm})\right]$ of Ca and $\mathrm{Mg}$ in irrigation well-water as determined by inductively couple plasma-optical emission spectroscopy [ICP-OES (IRIS 1000 HR Duo; Thermo Elemental, Franklin, MA)] (Physical and Aggregate Properties, Alkalinity: Hardness by Calculation, 1998). Treatments consisted of irrigation water without neutralization [high alkalinity (H-A) (control, not acidified)] or irrigation treated with acid to neutralize alkalinity at two levels: medium alkalinity (M-A) or low alkalinity (L-A). Treatments H-A, $\mathrm{M}-\mathrm{A}$, and $\mathrm{L}-\mathrm{A}$ had $\mathrm{CaCO}_{3}$ meq. $\mathrm{L}^{-1}$ levels of 5,3 , and 1 , respectively. Treatments (800$1000 \mathrm{~mL}$ ) were applied every other day or as needed with an average collected leachate volume of $255 \mathrm{~mL}[ \pm 12.4 \mathrm{~mL}$ (standard error of the mean)], corresponding to a leaching fraction of 0.32 . Irrigation water to prepare treatments was collected from the nursery for each application.

Plant growth and quality. Plants were sheared/pruned to the side of pots and to height from the substrate surface to 25.4 , $30.5,40.6,25.4,35.6$, and $45.7 \mathrm{~cm}$ on days $58,120,181,241,304$, and 358 of the study, respectively, to control plant shape and form as would be done at the nursery for this crop to maintain a suitable plant form during the production cycle. Total biomass from each shearing event was collected and fresh weighed (FW) and recorded. Growth index [height + width 1 (north-south) + width 2 (east-west)/3] was determined weekly starting at week 9 except for weeks 13, 15, 17, 31, 47, and 48. Leaf greenness was determined by the SPAD meter (502-Plus; Konica Minolta Sensing, Inc., Japan) weekly starting at week 2, except for weeks 13, 15, 17, 19, 27,

Table 1. Substrate components, amendments, and formulation that plants were growing in when received from the nursery.

\begin{tabular}{ll}
\hline Media composition & \\
Physical components & \\
Peat $^{\mathrm{z}}$ & $45 \%$ \\
Bark $^{\mathrm{y}}$ & $45 \%$ \\
Sand $^{\mathrm{x}}$ & $10 \%$ \\
${\text { Amendments }\left(\mathrm{kg} \cdot \mathrm{m}^{-3}\right)}$ Osmocote $20-8-5-9^{\mathrm{w}}$ & \\
Harrells minors $^{\mathrm{v}}$ & 8.90 \\
Iron sulfate $^{\mathrm{u}}$ & 1.19 \\
Dolomite $^{\mathrm{t}}$ & 1.19 \\
Calcium hydrate $^{\mathrm{s}}$ & 2.37 \\
Talstar $^{\mathrm{r}}$ & 5.93 \\
Formulated $\mathrm{pH}^{\mathrm{pH}}$ & 1.19 \\
\end{tabular}

${ }^{\mathrm{z}}$ Florida peat.

${ }^{\text {y} A g e d ~ p i n e ~ b a r k . ~ T i m e ~ b a r k ~ w a s ~ " a g e d " ~ a n d ~ w a s ~}$ undefined on substrate invoice.

${ }^{\mathrm{x}}$ Department of Transportation course grade sand (aggregate size undefined on substrate invoice).

wOsmocote, The Scotts Company, LLC, Marysville, OH. Fertilizer composition given as $\mathrm{N}-\mathrm{P}-\mathrm{K}-\mathrm{Mg}$. Nitrogen $(\mathrm{N}): 6.87$ ammoniacal-N, 5.87 nitrate- $\mathrm{N}$, and $6.29 \%$ urea-N. Micronutrients: $\mathrm{Cu}, \mathrm{Fe}, \mathrm{Mn}$, and $\mathrm{Zn}$.

${ }^{\mathrm{v}}$ Harrells, Lakeland, FL. Micronutrient elements or concentration in "Minors," undefined.

"Iron sulfate $\left(\mathrm{FeSO}_{4}\right)$ source was undefined on substrate invoice.

${ }^{t}$ Dolomite $\left[\mathrm{CaMg}\left(\mathrm{CO}_{3}\right)_{2}\right]$ source was undefined on substrate invoice.

${ }^{\mathrm{s}}$ Calcium hydrate $\left[\mathrm{Ca}(\mathrm{OH})_{2}\right]$ source was undefined on substrate invoice.

${ }^{\mathrm{r}}$ Talstar, FMC, Corp., Philadelphia, PA.

${ }^{\mathrm{q}} \mathrm{pH}$ : Indicated on substrate invoice.

\section{Greenhouse Temperature}

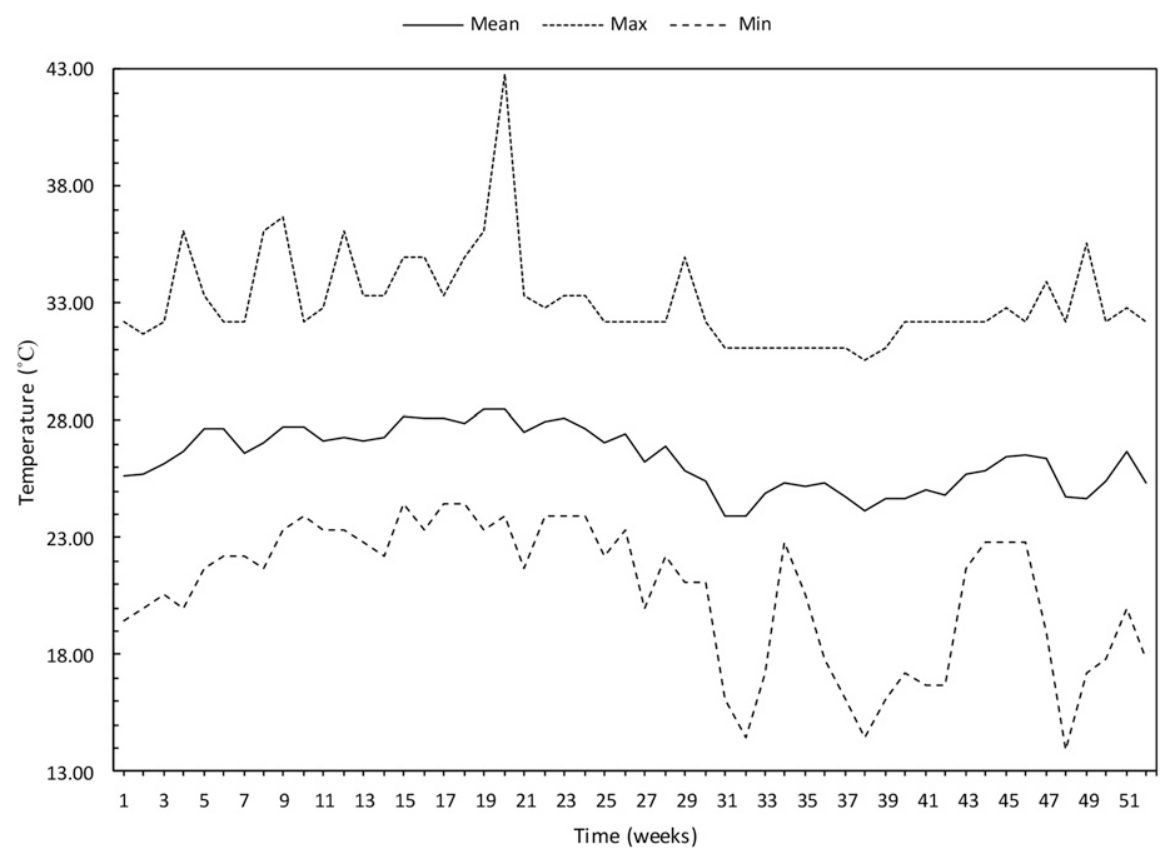

Fig. 2. Greenhouse temperature over the 52-week study with week-1 starting in March. 
$28,31,34,36,37,45,46,47$, and 48 . SPAD readings were assessed on six randomlyselected, recently-matured, leaves per plant.

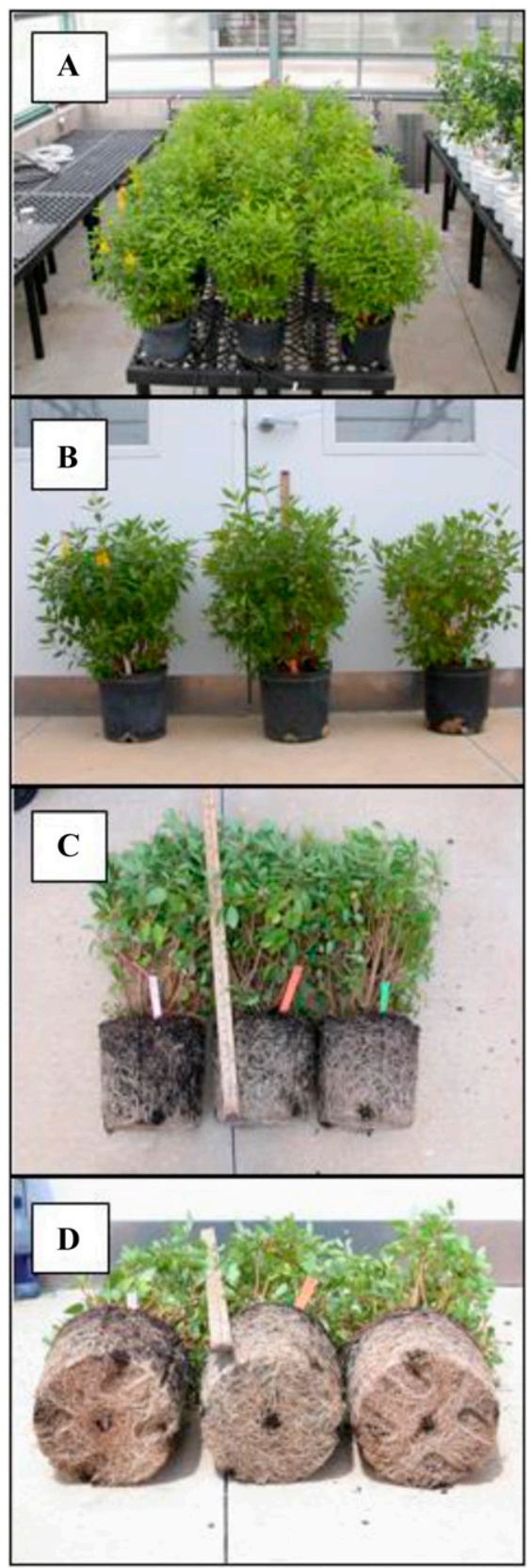

Fig. 3. (A) Representative picture of experimental layout of Thryallis plants in the study. For pictures B-D, treatments are from left to right: High-Alkalinity (H-A), Medium-Alkalinity (M-A), and Low-Alkalinity (L-A) at 51 (B) or $52[(\mathbf{C}$ and $\mathbf{D})$ (harvest/end of the study)] weeks after the start of the study. Plants are the same for pictures B-D. (B) Representative view of plant tops/canopy before plants received their final shearing. (C) Side view of root growth, and (D) bottom view of root growth.
Inflorescence was determined at harvest by counting total flower spikes [not individual flowers (Fig. 4)] per plant, and root systems were visually (qualitatively) surveyed for growth and quality at harvest. Plant tops were also surveyed on a 1 (unacceptable plant aesthetics) to 5 (superior plant aesthetics) scale at harvest, 52 weeks after the start of the experiment.

Leaf mineral determination. Recently matured leaves (200 g FW per plant) were harvested on day 365 of the study for nutrient analysis. Leaf tissue was washed for $15 \mathrm{~s}$ each in DI (deionized) water, $0.01 \%$ detergent (Citranox, Alconox, Inc., White Plains, $\mathrm{NY}$ ), and $0.1 \mathrm{~N} \mathrm{HCl}$ solution, followed by three more rinses in DI water, dried at $80{ }^{\circ} \mathrm{C}$ for $48 \mathrm{~h}$ in a forced-air oven, dry weight recorded, and leaf tissue milled to pass a 20 -mesh screen. Leaf tissue $(500 \mathrm{mg})$ was digested in $10 \mathrm{~mL}$ of concentrated $\mathrm{HNO}_{3}$ (trace metal grade) at $2068.5 \mathrm{kPa}$ and $170{ }^{\circ} \mathrm{C}$ for $10 \mathrm{~min}$ in a microwave (model Mars 5 , CEM Corp., Mathews, NC) according to the U.S. Environmental Protection Agency (USEPA) Method 3052 (1996). Leaf digestates were brought to volume in $100 \mathrm{~mL}$ volumetric flasks and filtered (no. 541; Whatman Paper, Maidstone, Kent, United Kingdom). Foliar levels of $\mathrm{Ca}$, copper $(\mathrm{Cu})$, iron (Fe), $\mathrm{K}, \mathrm{Mg}$, manganese (Mn), phosphorous $(\mathrm{P})$, and zinc $(\mathrm{Zn})$ were determined by ICPOES according to USEPA Method 6010C (U.S. Environmental Protection Agency, 2000). Leaf nitrogen $(\mathrm{N})$ was determined by flash-combustion/GC separation (NC 2100; CE Elantach, Lakewood, NJ) operated with the following parameters: 900 and $840{ }^{\circ} \mathrm{C}$ for the first and second columns, respectively, and a carrier gas [helium $(\mathrm{He})]$ flow rate of $140 \mathrm{~mL} \cdot \mathrm{min}^{-1}$.

Substrate analysis. Substrate soluble minerals, $\mathrm{pH}$, and EC were determined on the extracts obtained using a modified 1:2 dilution method as described by Lang (1996) on day 365 of the study (harvest). Substrate $\left(200 \mathrm{~cm}^{3}\right)$ was diluted with $400 \mathrm{~mL}$ of DI

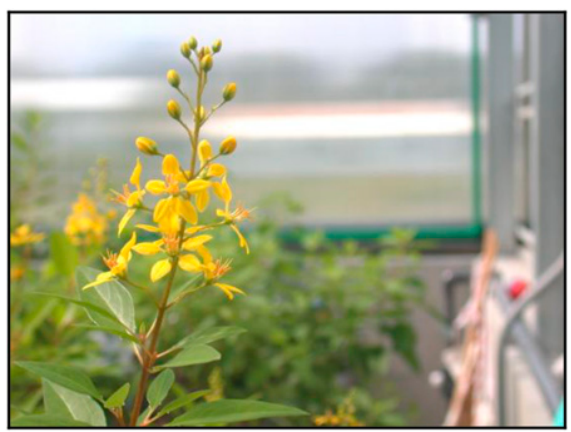

Fig. 4. Representative infloresence/flower spike of golden-yellow followers for Thryallis in the study. water, stirred, allowed to equilibrate for $45 \mathrm{~min}$, and then gravity filtered (no. 541 Whatman). Nutrients, $\mathrm{Ca}, \mathrm{Cu}, \mathrm{Fe}, \mathrm{K}, \mathrm{Mg}, \mathrm{Mn}, \mathrm{P}$, and $\mathrm{Zn}$ were determined by ICP-OES as previously described. ICP-OES MDLs (minimum detection limits) were $\left(\mu \mathrm{g} \cdot \mathrm{L}^{-1}\right) \mathrm{Ca}(0.06), \mathrm{Cu}(0.02)$, $\mathrm{Fe}(0.09), \mathrm{K}(0.40), \mathrm{Mg}(0.10), \mathrm{Mn}(0.01)$, $\mathrm{P}(0.16)$, and $\mathrm{Zn}(0.01)$. pH was determined using a combination glass electrode (Fisher Scientific, Accument 13-620-185) and meter (Fisher Scientific, AR50) calibrated with $\mathrm{pH}$ standards 4,7 , and $10\left(r^{2} \geq 0.98\right)$. EC was measured using a temperature-compensated electrode (Thermo Scientific, Orion, 013010MD, Waltham, MA) and meter (Thermo Scientific, Orion 4 Star) calibrated with $1413 \mu \mathrm{S} \cdot \mathrm{cm}^{-1}$ standard (Fisher Scientific, Traceable Conductivity Standard 09-328-11).

Experimental design and statistical analysis. Experimental units (containers/ plants) were arranged on a greenhouse bench using a completely randomized designed with three water alkalinity levels (H-A, M-A, and L-A) and six replications per alkalinity level treatment were made. Data were analyzed by analysis of variance (ANOVA) to determine significance of main effects and interactions $(P \leq 0.05)$. Calculations were performed with the general linear model procedure of SAS (SAS Institute, Cary, NC). Where ANOVA detected significance, means were separated, and planned comparisons were made using least significant difference (LSD).

\section{Results and Discussion}

Irrigation water chemistry. For the nutrients analyzed, the well-water irrigation source from the nursery contained $\mathrm{Ca}, \mathrm{K}$, and $\mathrm{Mg}$ in the $\mathrm{mg} \cdot \mathrm{L}^{-1}$ range and $\mathrm{Cu}, \mathrm{Fe}, \mathrm{Mn}$, $\mathrm{P}$, and $\mathrm{Zn}$ in the $\mu \mathrm{g} \cdot \mathrm{L}^{-1}$ range (Table 2) with a pH of 7.4 and EC of $0.8 \mathrm{mS} \cdot \mathrm{cm}^{-1}$ (Table 3 ). Neutralizing alkalinity with sulfuric acid significantly affected $\mathrm{pH}$ but not EC (Table 3). The indirect method for determining alkalinity $\left(311 \mathrm{mg} \cdot \mathrm{L}^{-1} \quad \mathrm{CaCO}_{3}\right)$ overestimated total carbonates by $16 \%$ compared with the direct method $\left(260 \mathrm{mg} \cdot \mathrm{L}^{-1} \mathrm{CaCO}_{3}\right)$. The indirect method for estimating carbonates assumes that all soluble $\mathrm{Ca}$ and $\mathrm{Mg}$ are associated with carbonates/bicarbonates. In the irrigation water collected from the commercial nursery used in this study, only $84 \%$ of $\mathrm{Ca}$ and $\mathrm{Mg}$ were associated with carbonates/bicarbonates. Regardless, irrigation water analysis by both the direct (i.e., titration) and indirect (i.e., calculation) methods for determining alkalinity revealed carbonate levels $\left(286 \mathrm{mg} \cdot \mathrm{L}^{-1}\right.$ as an average of both methods) was considered undesirable $\left(>214 \mathrm{mg} \cdot \mathrm{L}^{-1}\right)$ for containerized nursery plant production and a potential problem for leaf residue staining (Table 4) (Department

Table 2. Inherent nutrient levels $( \pm \mathrm{SE})$ for well-water collected at the nursery over the course of the 52-week study. Treatment is High-Alkalinity (H-A).

\begin{tabular}{|c|c|c|c|c|c|c|c|c|c|}
\hline & $\mathrm{Ca}$ & $\mathrm{K}$ & $\mathrm{Mg}$ & $\mathrm{S}$ & $\mathrm{P}$ & $\mathrm{Cu}$ & $\mathrm{Fe}$ & $\mathrm{Mn}$ & $\mathrm{Zn}$ \\
\hline Alkalinity level & \multicolumn{4}{|c|}{$\left(\mathrm{mg} \cdot \mathrm{L}^{-1}\right)$} & \multicolumn{5}{|c|}{$\left(\mu \mathrm{g} \cdot \mathrm{L}^{-1}\right)$} \\
\hline H-A (control) & $97.4 \pm 4.3$ & $1.3 \pm 0.2$ & $10.5 \pm 0.4$ & $2.7 \pm 0.1$ & $145.5 \pm 14.6$ & $6.9 \pm 0.6$ & $27.2 \pm 4.8$ & $31.2 \pm 4.00$ & $17.1 \pm 2.7$ \\
\hline
\end{tabular}


of Agriculture and Consumer Services, 2014; Yeager et al., 1997). Neutralizing alkalinity with $\mathrm{H}_{2} \mathrm{SO}_{4}$ did not alter irrigation water nutrient levels or significantly affect EC between treatments (Table 3), but $\mathrm{pH}$ dropped 1.0 and $2.6 \mathrm{pH}$ units for the M-A and L-A treatment, respectively, compared with the control (H-A) with the addition of acid (Table 3). Irrigation water $\mathrm{pH}$ (7.4), in addition to alkalinity, was also considered high $(>7.0)$ for containerized nursery plant production [Table 3 (H-A) (Yeager et al., 1997)]. Irrigation water sulfur levels were affected with the addition of sulfuric acid to neutralize alkalinity (Table 3 ).

Substrate solution chemistry. Treatment was significant for $\mathrm{pH}$ but not for EC. There was a $1.51 \mathrm{pH}$ unit drop, i.e., more acidic, from the H-A to the L-A treatment (Table 4). Optimal substrate $\mathrm{pH}$ varies with crop, but a general range of 4.5-6.5 is considered good for most nursery crops (Yeager et al., 2013). Thyrallis is a crop that can tolerate a broad substrate $\mathrm{pH}$ range from slightly basic to acidic [Gilman, 1999 (numerical pH range not given)]. So using the broad $\mathrm{pH}$ range interpretation, substrate $\mathrm{pH}$ for all treatAs previously mentioned, there are many reports, however, that plant species vary in susceptibility to alkalinity (Bell et al., 1993; Valdez-Aguilar and Reed, 2007). For substrate nutrients, treatment was not significant for $\mathrm{Cu}, \mathrm{Fe}, \mathrm{K}, \mathrm{Mg}$, or $\mathrm{P}$, but was significant ments was adequate for the crop in this study.

for $\mathrm{Ca}, \mathrm{Mn}$, and $\mathrm{Zn}$ (Table 4). Calcium, Mn, and $\mathrm{Zn}$ were $148 \%, 546 \%$, and $430 \%$ greater in the L-A treatment than the control (H-A treatment). For $\mathrm{Mn}$ and $\mathrm{Zn}$, this is the result of substrate $\mathrm{pH}$ where these metals become more soluble as substrate becomes more acidic. The reason why similar results were not observed for $\mathrm{Cu}$ and $\mathrm{Fe}$ in substratesolution, micronutrient metals that also become more soluble as $\mathrm{pH}$ becomes more acidic, is unknown, but possibly the result of these metals binding to substrate physical components like peat, bark, or both more strongly than Mn or Zn (Crist et al., 1996; Demirbas, 2008). For $\mathrm{Ca}$, as calcium carbonate reacts with sulfuric acid, $\mathrm{Ca}$ may bind with other ions becoming more soluble. EC over the course of the 52-week study averaged $1.17 \mathrm{mS} \cdot \mathrm{L}^{-1}$, which was slightly higher than those considered desirable for the production of most nursery crops fertilized with CRF [Table 4 (Yeager et al., 2013)].

Plant growth and nutrition. At harvest, 52 weeks after starting treatments, there was no difference in inflorescence/flower spike (Fig. 4) count between treatments, averaging $3.39[ \pm 0.42$ (SE of the mean)] per plant (data not shown). Treatments did have an effect, however, on growth index, shearing/pruned biomass, and SPAD with the M-A treatment being significantly greater than either the $\mathrm{H}-\mathrm{A}$ or L-A treatments which did not differ from each other (Table 5). Plants were surveyed for quality with the H-A and M-A

Table 3. Treatment solution (irrigation water chemistry) $\mathrm{pH}, \mathrm{EC}$, and volume of sulfuric acid to neutralize $0 \%, 40 \%$, and $80 \%$ neutralization of alkalinity over the 52 -week course of the study, \pm SE. Treatments: High-Alkalinity (H-A), Medium-Alkalinity (M-A), and Low-Alkalinity (L-A).

\begin{tabular}{lcccc}
\hline Alkalinity level & $\mathrm{pH}$ & $\mathrm{EC}\left(\mathrm{mS} \cdot \mathrm{cm}^{-1}\right)$ & Sulfur $\left(\mathrm{mg} \cdot \mathrm{L}^{-1}\right)$ & $\mathrm{H}_{2} \mathrm{SO}_{4}\left(\mu \mathrm{L}^{-\mathrm{L}^{-1}}\right)^{\mathrm{z}}$ \\
\hline H-A & $7.4 \pm 0.0$ & $0.8 \pm 0.1$ & $2.7 \pm 0.1$ & 0 \\
M-A & $6.4 \pm 0.1$ & $0.9 \pm 0.1$ & $44.6 \pm 0.1$ & $82 \pm 8$ \\
L-A & $4.8 \pm 0.2$ & $0.9 \pm 0.1$ & $92.0 \pm 0.8$ & $164 \pm 16$ \\
\hline
\end{tabular}

${ }^{\mathrm{z}}$ Sulfuric acid, $36 \mathrm{~N}$, Certified ACS Plus, A300-212, Fisher Scientific. treatments not significantly different and the L-A treatment scoring a significantly different lower score (Fig. 3B; Table 5). A qualitative survey of root systems at harvest showed that the M-A and L-A treatment root systems were greater than the $\mathrm{H}$-A treatment based on visual side-wall root development (Fig. 3C and D). Bell et al. (1993) also found changes in root systems with a level of alkalinity. The most sensitive plants to alkalinity in their study showed symptoms of nutrient deficiency, with leaf wilting and necrosis and degeneration of root systems. This was attributed to the inability of root systems to physiologically and structurally function normally under high alkalinity conditions. Other studies have found that plants vary in susceptibility to alkalinity and at alkalinity levels lower than generally considered safe, i.e., $<214 \mathrm{mg} \cdot \mathrm{L}^{-1}$ bicarbonate. Kuehny and Morales (1998) looked at the effects of salinity and alkalinity on pansy and impatiens grown in three different substrates (peat, peat and pine bark, or pine bark) under greenhouse conditions. They found that irrigation water with $\geq 200 \mathrm{mg} \cdot \mathrm{L}^{-1} \mathrm{HCO}_{3}{ }^{-}$from sodium bicarbonate $\left(\mathrm{NaHCO}_{3}\right)$ was associated with reduced plant growth, decreased flower number, general leaf chlorosis, and some leaf deformation and necrosis.

Foliar mineral concentration was not different between treatments for $\mathrm{Ca}, \mathrm{Mg}$, and $\mathrm{Cu}$ (Table 6). Iron, $\mathrm{Mn}$, and $\mathrm{Zn}$ foliar concentration increased by $39 \%, 120 \%$, and $36 \%$, respectively, in the L-A treatment compared with the control H-A (Table 6). Potassium decreased 5\% in the L-A treatment compared with the control H-A. Although not practically significant, nutrient level-wise (i.e., not of consequence to plant production), $\mathrm{P}$ was the only foliar nutrient analyzed that was significantly greater at M-A than in either the $\mathrm{H}-\mathrm{A}$ or L-A treatments, which were not different (Table 6). Interpreting foliar

Table 4. Media analysis by the 2:1 method at harvest, 52 weeks after the start of the study, $n=6$. Treatments: High-Alkalinity (H-A), Medium-Alkalinity (M-A), and Low-Alkalinity (L-A).

\begin{tabular}{|c|c|c|c|c|c|c|c|c|c|c|}
\hline \multirow[b]{2}{*}{ Alkalinity level } & \multicolumn{4}{|c|}{ Macronutrients $\left(\mathrm{mg} \cdot \mathrm{L}^{-1}\right)$} & \multicolumn{4}{|c|}{ Micronutrients $\left(\mu \mathrm{g} \cdot \mathrm{L}^{-1}\right)$} & \multicolumn{2}{|c|}{ Chemistry } \\
\hline & $\mathrm{Ca}$ & $\mathrm{K}$ & $\mathrm{Mg}$ & $\mathrm{P}$ & $\mathrm{Cu}$ & $\mathrm{Fe}$ & $\mathrm{Mn}$ & $\mathrm{Zn}$ & $\mathrm{pH}$ & $\mathrm{EC}\left(\mathrm{mS} \cdot \mathrm{cm}^{-1}\right)$ \\
\hline$\overline{\mathrm{H}-\mathrm{A}}$ & $51.0 \mathrm{~b}^{\mathrm{z}}$ & $7.9 \mathrm{a}$ & $7.7 \mathrm{a}$ & $2.8 \mathrm{a}$ & $23.3 \mathrm{a}$ & $29.7 \mathrm{a}$ & $153.3 \mathrm{~b}$ & $81.7 \mathrm{~b}$ & $6.2 \mathrm{a}$ & $0.8 \mathrm{a}$ \\
\hline M-A & $111.4 \mathrm{ab}$ & $9.5 \mathrm{a}$ & $12.8 \mathrm{a}$ & $2.9 \mathrm{a}$ & $20.0 \mathrm{a}$ & $33.7 \mathrm{a}$ & $448.3 \mathrm{ab}$ & $236.7 \mathrm{ab}$ & $5.2 \mathrm{~b}$ & $1.5 \mathrm{a}$ \\
\hline L-A & $126.3 \mathrm{a}$ & $6.3 \mathrm{a}$ & $11.7 \mathrm{a}$ & $2.8 \mathrm{a}$ & $21.7 \mathrm{a}$ & $29.5 \mathrm{a}$ & $990.0 \mathrm{a}$ & $433.3 \mathrm{a}$ & $4.7 \mathrm{c}$ & $1.2 \mathrm{a}$ \\
\hline
\end{tabular}

${ }^{\mathrm{z}}$ Means followed by the same letter within a column are not significantly different at $P<0.05$, mean separation by LSD.

Table 5. Average growth index [height + width $1+$ width 2 (perpendicular to width 1)/3] per plant growth index was determined weekly starting with week 9 except for weeks $13,15,17,31,47$, and 48, over the 52-week study. $n=276$ [(52 weeks -6 weeks $) \times 6$ (reps per treatment)]. Average fresh weight [FW (g)] sheared/pruned per plant over the 52 -week study. Plants were sheared/pruned to side of pots and to height from substrate surface to $25.4 \mathrm{~cm}$ ( 10 inches), $30.5 \mathrm{~cm}$ (12 inches), $40.6 \mathrm{~cm}$ (16 inches), $25.4 \mathrm{~cm}$ (10 inches), $35.6 \mathrm{~cm}$ (14 inches), and $45.7 \mathrm{~cm}$ (18 inches), on days 58, 120, 181, 241, 304, and 358 of the study, respectively, to control plant shape and form as would be done at the nursery for this crop to maintain a suitable plant form during the production cycle. $n=36$ ( 6 weeks $\times 6$ reps per treatment). SPAD, a measure of leaf greenness, was determined weekly starting at week 2 , except for weeks $13,15,17,19,27,28,31,34$, $36,37,55,46,47$, and 48. SPAD readings were assessed on six randomly selected, recently matured, leaves per plant. $n=228[(52$ weeks -14 weeks $) \times(6$ reps per treatment)]. Qualitative assessment of plant quality based on a 1 to 5 scale where 1: poor quality with no economic value (i.e., would not purchase), 3: plants of acceptable quality with economic value (i.e., would purchase at right price), and 5: plants of exceptional quality, with high economic value (i.e., would pay a premium for plants). $n=6$. Treatments: High-Alkalinity (H-A), Medium-Alkalinity (M-A), and Low-Alkalinity (L-A).

\begin{tabular}{lccc}
\hline Alkalinity level & Growth index $(\mathrm{cm})$ & Shearing/clippings (FW g) & SPAD (units) \\
H-A & $17.9 \mathrm{~b}^{\mathrm{z}}$ & $228.1 \mathrm{~b}$ & $35.2 \mathrm{~b}$ \\
M-A & $18.5 \mathrm{a}$ & $245.1 \mathrm{a}$ & $3.2 \mathrm{a}$ \\
L-A & $17.8 \mathrm{~b}$ & $215.6 \mathrm{~b}$ & $3.5 \mathrm{a}$ \\
\hline
\end{tabular}

${ }^{\mathrm{z}}$ Means followed by the same letter within a column are not significantly different at $P<0.05$, mean separation by LSD. 
Table 6. Plant tissue analysis at harvest over the course of the experiment. Sampling, $150 \mathrm{~g}$ fresh weight, occurred on day 1 and before each shearing (6). Treatments: High-Alkalinity (H-A), Medium-Alkalinity (M-A), and Low-Alkalinity (L-A). $n=7$.

\begin{tabular}{|c|c|c|c|c|c|c|c|c|c|}
\hline \multirow[b]{2}{*}{ Alkalinity level } & \multicolumn{5}{|c|}{ Macronutrients (\%) } & \multicolumn{4}{|c|}{ Micronutrients $\left(\mu g \cdot g^{-1}\right)$} \\
\hline & $\mathrm{Ca}$ & $\mathrm{K}$ & $\mathrm{Mg}$ & $\mathrm{N}$ & $\mathrm{P}$ & $\mathrm{Cu}$ & $\mathrm{Fe}$ & $\mathrm{Mn}$ & $\mathrm{Zn}$ \\
\hline$\overline{\mathrm{H}-\mathrm{A}}$ & $1.3 \mathrm{a}$ & $0.9 \mathrm{a}^{\mathrm{zy}}$ & $0.4 \mathrm{a}$ & $2.0 \mathrm{a}$ & $0.2 \mathrm{a}$ & $6.0 \mathrm{a}$ & $94.9 \mathrm{~b}$ & $109.8 \mathrm{c}$ & $45.3 \mathrm{c}$ \\
\hline $\mathrm{M}-\mathrm{A}$ & $1.3 \mathrm{a}^{\mathrm{z}}$ & $0.9 \mathrm{ab}$ & $0.4 \mathrm{a}$ & $2.0 \mathrm{a}$ & $0.2 \mathrm{~b}$ & $6.6 \mathrm{a}$ & $109.0 \mathrm{ab}$ & $146.0 \mathrm{~b}$ & $51.9 \mathrm{~b}$ \\
\hline L-A & $1.3 \mathrm{a}^{\mathrm{z}}$ & $0.9 \mathrm{~b}$ & $0.4 \mathrm{a}$ & $1.9 \mathrm{a}$ & $0.2 \mathrm{a}$ & $5.6 \mathrm{a}$ & $132.1 \mathrm{a}$ & $241.9 \mathrm{a}$ & $61.6 \mathrm{a}$ \\
\hline
\end{tabular}

${ }^{\mathrm{z}}$ Means followed by the same letter within a column are not significantly different at $P<0.05$, mean separation by LSD.

${ }^{\mathrm{y}}$ Differences between means at the tenths place: H-A, 0.93\%; M-A, $0.92 \%$; and L-A, $0.88 \%$.

nutrient levels, for all treatments, $\mathrm{Mg}, \mathrm{N}, \mathrm{P}$, $\mathrm{Cu}$, and $\mathrm{Zn}$ were sufficient. Calcium and $\mathrm{Mn}$ for all treatment levels were higher than what is generally considered sufficient. Iron for the H-A treatment was slightly lower than what is generally considered sufficient for normal plant growth with the M-A and L-A treatments being sufficient (Table 6) (Yeager et al., 2013).

In this long-term study, micronutrient disorders did not develop in the H-A treatment as was observed in the nursery (Fig. 1). This could be due to several factors including differences in substrate and fertilizers [three different substrate compositions and various fertilizer types and rates were used on the nursery, in addition to different times of fertilizer application during the production schedule (personal communication with the production manager)]. It is also likely that irrigation water application was greater on the nursery and climatic conditions more variable in the field. Greater irrigation volume could result in increased leaching of nutrients from the substrate where it would otherwise be available for plant uptake, reducing the availability of certain nutrients in the substrate solution because of the effects of high alkalinity, inability to take up nutrients due to possible reduced root growth due to high alkalinity, or a combination of these factors.

\section{Conclusion}

Regardless of the results of this study, in particular, the lack of nutrient disorder, irrigation water $\mathrm{pH}$, and alkalinity on the nursery warranted treatment by acidification based on BMP recommendations. Under the conditions of the study, the M-A treatment was most favorable for plant production for thyrallis with greater growth, producing more biomass as a mean of shearing, and greener leaves based on SPAD readings. The substrate analysis of the M-A treatment also had high levels of soluble nutrients and a favorable $\mathrm{pH}$ that fell between the recommended $\mathrm{pH}$-range for most nursery crops. Therefore, based on data presented here, the M-A treatment was suitable for the long-term production of thryallis with the H-A and L-A treatments being the extremes with time.

\section{Literature Cited}

Baily, D.A. 1996. Alkalinity, pH, and acidification, p. 69-91. In: D.W. Reed (ed.). Water, media, and nutrition for greenhouse crops. Ball, Batavia, IL.

Bell, D.T., C.F. Wilkins, P.G. Moezel, and S.C. Ward. 1993. Alkalinity tolerance of woody species used in bauxite waste rehabilitation, western Australia. Restor. Ecol. 1:51-58.

Coulombre, B.A., R.L. Cjaney, and W.J. Wiebold. 1984. Bicarbonate directly induces iron chlorosis in susceptible soybean cultivars. Soil Sci. Soc. Amer. J. 48:1297-1300.

Crist, R.H., J.R. Martin, J. Chonko, and D.R. Crist. 1996. Uptake of metals on peat moss: An ionexchange process. Environ. Sci. Technol. 30: 2456-2461.

De la Guardia, M.D. and E. Alcántara. 2002 Bicarbonate and low iron level increase root to total shoot plant weight ratio in olive and peach rootstock. J. Plant Nutr. 25:1021-1032.

Demirbas, A. 2008. Heavy metal adsorption onto agro-based waste materials: A review. J. Hazard. Mater. 157:220-229.

Department of Agriculture and Consumer Services. 2014. Water quality/quantity best management practices for Florida nurseries. 6 Mar. 2017. <http://www.freshfromflorida. com/content/download/37570/848371/NurseryBMP.pdf $>$.

Fish, J.E. and M.T. Stewart. 1991. Hydrology of the surficial aquifer system, Dade, County, Florida. USGS. WRIR 904108

Gilman, E.F. 1999. Galphimia glauca. Univ. of Fla. Coop. Ext. Ser. Fact Sheet, FPS-219.

Kidder, G. and E.A. Hanlon , Jr. 1997. Neutralizing excess bicarbonates from irrigation water. Univ. of Fla. Coop. Ext. Ser. Circ. SL-142.

Kuehny, J.S. and B. Morales. 1998. Effects of salinity and alkalinity on pansy and impatiens in three different growing media. J. Plant Nutr. 21:1011-1023.

Lang, H.J. 1996. Growing media testing and interpretation, p. 123-139. In: D.W. Reed (ed.). Water, media, and nutrition for greenhouse crops. Ball, Batavia, IL.

Li, Y. and M. Zhang. 2002. Effects of urea and nitric acid on water quality and on response of anthurium. HortTechnology 12:131-134.
Physical and aggregate properties, Alkalinity: Titration method, Method 2320B p. 2-26. 1998. In: A.D. Eaton, L.S. Clesceri, and A.E. Greenberg (eds.). Standard methods for the examination of water and waste water. 20th ed. Amer. Public Health Assn., Washington, DC.

Physical and aggregate properties, Hardness by calculation, Method 2340B, p. 2-36. 1998. In: A.D. Eaton, L.S. Clesceri, and A.E. Greenberg (eds.). Standard methods for the examination of water and waste water. 20th ed. Amer. Public Health Assn., Washington, DC.

Reese, R.S. and K.J. Cunningham. 2000. USGS. WRIR 994213.

Roosta, H.R. 2011. Interaction between water alkalinity and nutrient solution $\mathrm{pH}$ on the vegetative growth, chlorophyll fluorescence and leaf magnesium, iron, manganese, and zinc concentration in lettuce. J. Plant Nutr. 34:717731.

Ruter, J.M. 2013. Importance of water quality in container plant production. USDA Forest Serv. Proc. RMRS-P 69:36-38.

U.S. Environmental Protection Agency. 1996. Method 3052: Microwave assisted acid digestion of siliceous and organically based matrices. $<$ http://www.caslab.com/EPA-Methods/ PDF/EPA-Method-3052.pdf $>$.

U.S. Environmental Protection Agency. 2000 Method 6010C: Inductively coupled plasmaatomic emission spectrometry. <http://www. caslab.com/EPA-Methods/PDF/EPA-Method6010-C.pdf>.

USDA, NRCS. 2016. The PLANTS database. 13 Sept. 2016. <http://plants.usda.gov> (National Plant Data Team, Greensboro, NC 27401-4901 USA).

Valdez-Aguilar, L.A. and D.W. Reed. 2007. Response of selected greenhouse ornamental plants to alkalinity in irrigation water. J. Plant Nutr. 30:441-452.

Yeager, T., T. Bilderback, D. Fare, C. Gilliam, A Niemiera, and K. Tilt. 1997. Best management practices: Guide for producing containergrown plants. Southern Nursery Assn., Atlanta, GA.

Yeager, T., T. Bilderback, D. Fare, C. Gilliam, J. Lea-Cox, A. Niemiera, J. Ruter, K. Tilt, S. Warren, T. Whitwell, and R. Wright. 2013. Best management practices: Guide for producing nursery crops. 3rd ed. Southern Nursery Assn., Acworth, GA. 